\title{
Utilization of Urea Super Granule in Raised Bed Versus Prilled Urea in Conventional Flat Method for Transplanted Aman Rice (Oryza Sativa)
}

\author{
Md. Halim Mahmud Bhuyan ${ }^{1, ~ *, ~ M o s t . ~ R a z i n a ~ F e r d o u s i ~}{ }^{2}$, Md. Toufiq Iqbal', \\ Ahamed Khairul Hasan ${ }^{3}$ \\ ${ }^{1}$ Department of Agronomy and Agricultural Extension, University of Rajshahi, Rajshahi, Bangladesh \\ ${ }^{2}$ Islamia Academy High School \& Agriculture College, Bagha, Rajshahi, Bangladesh \\ ${ }^{3}$ Department of Agronomy, Bangladesh Agricultural University, Mymensingh, Bangladesh \\ Email address: \\ drhalim.bhuyan@gmail.com (Md. H. M. Bhuyan) \\ ${ }^{*}$ Corresponding author
}

\section{To cite this article:}

Md. Halim Mahmud Bhuyan, Most. Razina Ferdousi, Md. Toufiq Iqbal, Ahamed Khairul Hasan. Utilization of Urea Super Granule in Raised Bed Versus Prilled Urea in Conventional Flat Method for Transplanted Aman Rice (Oryza Sativa). American Journal of Agriculture and Forestry. Vol. 4, No. 1, 2016, pp. 1-9. doi: 10.11648/j.ajaf.20160401.11

Received: January 30, 2016; Accepted: February 23, 2016; Published: March 22, 2016

\begin{abstract}
Bed planting with urea super granule (USG) application of rice production systems is very new and research on it is still at an introductory phase. Impact of granular urea application on growth and yield of transplanted aman rice as well as evaluation of water and fertilizer use efficiency of rice-fallow-rice cropping system was investigated under raised bed cultivation method. Result showed that the USG in bed planting method increased grain yield of transplanted aman rice up to $12.32 \%$ over prilled urea (PU) broadcasting in conventional method. The USG application in bed planting method increased the number of panicle $\mathrm{m}^{-2}$, number of grains panicle ${ }^{-1}$ and 1000-grains weight of rice than the PU in conventional method. Sterility percentage and weed infestation were lower at USG application in bed planting method than the PU in conventional method. Forty percent irrigation water and time for application could be saved through the USG in bed planting than the PU broadcasting in conventional method. Water use efficiency for grain and biomass production was higher by the USG application in bed planting than the PU broadcasting in conventional method. Likewise, agronomic efficiency of the USG in bed planting was higher than the PU broadcasting in conventional method. This study concluded that the USG in bed planting method is a new approach to get better fertilizer and water use efficiency as well as higher yield compared to the existing agronomic practice in the world.
\end{abstract}

Keywords: Agronomic Efficiency, Bed Planting, Prilled Urea, Rice, Urea Super Granule

\section{Introduction}

Paddy rice crop requires massive amounts of mineral nutrients especially nitrogen $(\mathrm{N})$ for its growth, development and yield (Goswami and Banerjee, 1978; Sahrawat, 2000). However, the efficiency of added $\mathrm{N}$ is very low, generally around $30-40 \%$ and in many cases even lowers (De Datta, 1978; Choudhury and Khanif, 2001). The low utilization efficiency is attributed to losses like volatilization, denitrification, leaching and surface run-off (Ponnamperuma, 1972; De Datta, 1981).
These losses can be reduced by management practices like use of modified forms of urea. This modified form of urea is called urea super granule (USG). The USG can be produced locally in the factory by using roll press machine. It is provided in deep point placement and has some advantages. These include (i) reduced $\mathrm{N}$ loss by runoff, volatilization and denitrification, (ii) delayed $\mathrm{N}$ uptake and (iii) reduced ammonium fixation (Westsellar, 1985).

Research showed that the superiority of USG over conventional prilled urea (PU) in rice production regarding $\mathrm{N}$ use efficiency (Cao et al., 1984; De Datta, 1987). Generally 
farmers are accustomed to using $\mathrm{N}$ fertilizer in the form of PU which is very easy to apply though rice plant can receive only 25 to $30 \%$ of applied fertilizer (BRRI, 2007). To reduce nitrogen loss, it is strongly considered that application of the USG is an important alternative that can increase the efficiency of $\mathrm{N}$ to about 20 to $25 \%$ and yield by 15 to $20 \%$ (BRRI, 2008).

Our previous study showed that water use efficiency for grain and biomass production was higher in bed planting than the conventional method (Bhuyan et al., 2012a, Bhuyan et al., 2012b). However, no study was undertaken for the USG application on bed planting as compared to the PU on conventional flat method. Therefore, this study was conducted to determine the role of USG on bed planting as compared to the conventional cultivation method. The hypothesis of this study is that the USG technique on raised bed will produce higher aman rice yield than the conventional PU technique.

\section{Materials and Methods}

\subsection{Experimental Site}

The experiment was conducted at the farmer's field located in the village of Daulatdiar of sadar Upa Zilla in Chuadanga district high Ganges river flood plain in Bangladesh. The experimental field is located at $23^{\circ} 39^{\prime} \mathrm{N}$ latitude and $88^{\circ} 49^{\prime} \mathrm{E}$ longitudes at a mean elevation of 11.58 $\mathrm{m}$ above the sea level. The soil of the experiment plot was silt loam with a $\mathrm{pH}$ of 7.30 . The average air temperature, relative humidity, rainfall and sunshine hours were $21.16^{\circ} \mathrm{C}$, $86.06 \%, 136.50 \mathrm{~mm}$ and 149.50 hours, respectively on the experimental field site.

\subsection{Raised Bed Preparation and Its Advantages}

Raised bed was prepared manually for the experiment. It can also be prepared through raised bed planting machine. Paddy rice crops were transplanted in two rows on top of the raised bed and irrigation water was applied within the furrows between the beds.

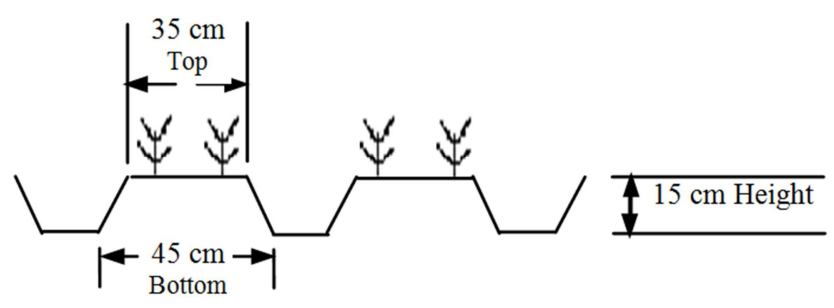

Fig. 1. Two rows rice on raised bed.

Water moves horizontally from the furrows into the beds. The height of the beds was maintained $15 \mathrm{~cm}$, top was $35 \mathrm{~cm}$ and bottom was $45 \mathrm{~cm}$ with 6 beds per plot (Fig. 1). The furrow width was $25 \mathrm{~cm}$. The major concern of raised bed technique is to enhance the productivity and save the irrigation water. Potential agronomic advantages of raised beds also include improved soil structure due to reduced compaction through controlled trafficking, reduced water logging and timelier of machinery operations due to better surface drainage.

\subsection{Conventional Flat Land Preparation and Its Drawbacks}

Land was prepared by puddling the soil in conventional method for transplanting paddy rice. The final land was prepared through ploughing and cross ploughing by two wheel power tiller with two laddering before two days of transplanting. The main difference between conventional flat and raised bed was furrow and transplanted aman rice on top of the bed in two rows. Conventional flat method also maintains continuing inundation until maturity. This affects soil physical, chemical and biological properties that influence the growing condition of paddy rice. In contrast, conventional flat method has some problems such as destruction of soil structure that leading to higher bulk density, higher soil penetration resistance and enhanced surface cracking.

\subsection{Experimental Design and Procedure}

Two planting methods for comparison of utilization of $\mathrm{N}$ fertilizer under conventional flooded and raised bed as well as furrows conditions were established across a soil. The combinations of treatments were deep placement of USG in raised bed and PU broadcasting in conventional flat method. Plots were $4 \mathrm{~m}$ wide $\times 2 \mathrm{~m}$ long. Two 30 day old seedlings hill $^{-1}$ of Swarna, a popular aman (July to November growing period) rice variety, were transplanted on $9^{\text {th }}$ August 2011 at a row to row and hill to hill spacing of $20 \mathrm{~cm}$ on both beds and the flat. Only two rows of rice were planted on each bed and plant density was much higher in the conventional treatment. Fertilizer was applied at the following rates: $\mathrm{N}=66, \mathrm{P}=5, \mathrm{~K}=18, \mathrm{~S}=6$ and $\mathrm{Zn}=0.5 \mathrm{~kg} \mathrm{ha}^{-1}$ applied as urea, triple super-phosphate (TSP), murate of potash (MP), gypsum and Zinc Sulphade $\left(\mathrm{ZnSO}_{4}\right)$, respectively. Whole of TSP, MP, gypsum and $\mathrm{ZnSO}_{4}$ were applied at the time of final land preparation as basal dose in the plots with conventional treatment. In the plots with bed planting treatments, the basal doses were applied before transplanting on the top of the beds. The conventional PU was top dressed in three equal splits at 15,30 and 50 days after transplanting (DAT) in conventional plot. In bed planting within a week after transplanting of aman rice, the USG briquettes are (1.8 gm weight) inserted into the puddled soil by hand, being placed to a depth of 7-10 $\mathrm{cm}$ (deep placement) in the middle of alternating squares of four hills of rice (BRRI, 2009).

\subsection{Crop Harvesting and Measurements}

Rice was harvested at $11^{\text {th }}$ November, 2011. Twenty randomly selected hills from each plot were used for agronomic measurements. A $1 \mathrm{~m}^{2}$ area from centre portion of each plot was harvested for determination of grain yield. Rice was threshed by using pedal thresher. Immediately after harvest grain moisture content and weight were recorded. 
Grain yield was adjusted to $14 \%$ moisture content.

\subsection{Water Management}

Conventional plots were continuously flooded to a depth of approximately $8 \mathrm{~cm}$ until drainage at $80 \%$ grain maturity about 2 weeks before harvest. In the raised bed-furrow system, enough irrigation water was kept in the furrows to just submerge the beds for seedling establishment and weed control during the first two weeks after transplanting. Thereafter, irrigation was scheduled to maintain a water head of about half the height of the beds never allowing the beds to be submerged throughout the growing season.

\subsection{Irrigated Water Measurement}

Irrigation water was measured by using a delivery pipe and water pan. A plastic delivery pipe was connected from the water pump to the experimental field. A water pan with 300 litre volume was filed by irrigation through the delivery pipe and time required was recorded. Then plots with different methods of planting were irrigation through the delivery pipe and times required were recorded. The amount of irrigation water applied in different plots was calculated as follows:

\author{
Amount of water applied per plot= \\ Volume of water pan $(\mathrm{L}) \times$ Time required to irrigation the plot $(\mathrm{sec})$
}

Time required filling the water pan $(\mathrm{sec})$

\subsection{Weeding}

Manual weeding was done twice in the transplant aman rice field during growth period. The plots were weeded at 15 and 30 DAT. Weed samples from each plot were collected at the time of weeding for comparing weed population and dry biomass yield of different treatments.

\subsection{Pest Control}

The rice was infested by stem borer at tillering stage and by rice bug at grain filling stage. Furadan $5 \mathrm{G}$ at the rate of 10 $\mathrm{kg} \mathrm{ha}^{-1}$ was applied at 40 DAT and Malathion 57 EC 5G at the rate of 1 litre $\mathrm{ha}^{-1}$ was applied at grain filling stage to control stem borer and rice bug, respectively.

\subsection{Water Use Efficiency Calculation}

Water use efficiency for grain and biomass production was calculated by the following equations:

Water use efficiency for grain production $\left(\mathrm{kg} \mathrm{ha}^{-1} \mathrm{~cm}^{-1}\right)=$ grain yield $\left(\mathrm{kg} \mathrm{ha}^{-1}\right) /$ total water required $(\mathrm{cm})$

Water use efficiency for biomass production $\left(\mathrm{kg} \mathrm{ha}^{-1} \mathrm{~cm}^{-1}\right)$ $=\left[\right.$ grain yield $\left(\mathrm{kg} \mathrm{ha}^{-1}\right)+$ straw yield $\left.\left(\mathrm{kg} \mathrm{ha}^{-1}\right)\right] /$ total water required $(\mathrm{cm})$

\subsection{Agronomic Efficiency of Fertilizer}

Agronomic efficiency (AE) of fertilizer was calculated by the following equation:

$$
\mathrm{AE}=\mathrm{GY}_{\mathrm{NA}}-\mathrm{GY}_{\mathrm{N} 0} / \mathrm{N}_{\mathrm{R}}
$$

Where $\mathrm{GY}_{\mathrm{NA}}=$ Grain yield $(\mathrm{kg} / \mathrm{ha})$ with addition of nutrient

$\mathrm{GY}_{\mathrm{N} 0}=$ Grain yield $(\mathrm{kg} / \mathrm{ha})$ without addition of nutrient

$\mathrm{N}_{\mathrm{R}}=$ Rate of added nutrient $(\mathrm{kg} / \mathrm{ha})$

\subsection{Statistical Analysis of Data}

Data were analysed following standard statistical procedure and means of treatments were compared based on the least significant difference test (LSD) at the 0.05 probability level.

\section{Results}

\subsection{Grain Yield and Yield Components}

The yield increased by $12.32 \%$ when urea super granule (USG) was used in bed planting over prilled urea (PU) broadcasting in conventional method. A similar finding was also found for the panicles, grains per panicle and $1000 \mathrm{gm}$ grain wt. The results were significantly different when compared to conventional method. Whereby the USG in bed planting had 9 panicle number $\mathrm{m}^{-2}, 20$ grain number per panicle and $0.24 \mathrm{gm}$ in 1000 grain wt more than PU in conventional method (Table 1).

Table 1. Grain yield and yield components with respect to urea super granule (USG) in raised bed and conventional prilled urea (PU) technique.

\begin{tabular}{lllll}
\hline \multirow{2}{*}{ Method of Fertilizer application } & \multicolumn{4}{l}{ Yield and yield components } \\
\cline { 2 - 5 } & Grain yield $\left(\mathbf{t ~ h a}^{-1}\right)$ & panicles $\mathbf{~ m}^{-2}(\mathbf{n o})$ & Grains panicle $^{-\mathbf{1}}(\mathbf{n o})$ & $\mathbf{1 0 0 0} \mathbf{~ g r a i n ~} \mathbf{w t}(\mathbf{g m})$ \\
\hline USG in bed planting & $4.92 \mathrm{a}$ & $285 \mathrm{a}$ & $160 \mathrm{a}$ & 23.12 \\
PU broadcasting in conventional planting & $4.38 \mathrm{~b}$ & $276 \mathrm{~b}$ & $140 \mathrm{~b}$ & 22.88 \\
LSD at 5\% & 0.013 & 3.215 & 2.618 & 0.840 \\
Level of significance & $* *$ & $* *$ & $* *$ & n.s. \\
\hline
\end{tabular}

Where n.s. and $* *$ represents probability of $>0.05$ and $\leq 0.01$, respectively. Values were means of three replicates.

\subsection{Other Plant Attributes}

Planting method affected plant height, panicle length, non-bearing tillers $\mathrm{m}^{-2}$, sterility percentage, straw yield and harvest index of rice. Plant height, panicle length and harvest index were higher by USG in bed planting than PU in conventional method. On the contrary, non-bearing tillers $\mathrm{m}^{-2}$, and sterility percentage were higher PU broadcasting in conventional method than the USG in bed 
planting. Likewise, lower number of non-bearing tillers $\mathrm{m}^{-2}$ was recorded by the USG in bed planting treatments than the PU in conventional method. The USG in bed planting significantly reduced the sterility percentage compared to the PU in conventional planting. In bed planting sterility was lower. The lower sterility might be accountable for higher grains in bed planting. The bed planting resulted in higher harvest index than conventional method (Table 2).

Table 2. Plant biomass with respect to USG in raised bed and PU application in conventional planting.

\begin{tabular}{|c|c|c|c|c|c|c|}
\hline $\begin{array}{l}\text { Method of fertilizer } \\
\text { application }\end{array}$ & Plant height (cm) & Panicle length (cm) & Non-bearing tiller $\left(n o-m^{-2}\right)$ & Sterility (\%) & Straw yield $\left(\right.$ tha $\left.^{-1}\right)$ & $\begin{array}{l}\text { Harvest } \\
\text { index }\end{array}$ \\
\hline USG in bed planting & $90.24 \mathrm{a}$ & 24.46 & $55 b$ & $9.78 b$ & $5.32 \mathrm{a}$ & $0.48 \mathrm{a}$ \\
\hline $\begin{array}{l}\text { PU broadcasting in } \\
\text { conventional planting }\end{array}$ & $86.38 b$ & 24.30 & $59 \mathrm{a}$ & $12.41 \mathrm{a}$ & $4.92 \mathrm{~b}$ & $0.47 \mathrm{~b}$ \\
\hline LSD at $5 \%$ & 1.114 & 0.281 & 2.225 & 0.379 & 0.125 & 0.109 \\
\hline Level of significance & $* *$ & n.s. & $* *$ & $* *$ & ** & $* *$ \\
\hline
\end{tabular}

Where n.s. and $*^{* *}$ represent probability of $>0.05$ and $\leq 0.01$, respectively. Values were means of three replicates.

\subsection{Tiller Production}

Transplanting of aman rice under different planting method affected the number of tillers $\mathrm{m}^{-2}$ of rice. The increasing trend of tiller $\mathrm{m}^{-2}$ was continued to 40 days after transplanting. At 40 days after transplanting both planting method attained the highest number of tiller $\mathrm{m}^{-2}$ and then started declining up to 100 days after transplanting (Table 3 ).

Table 3. Effect of tiller production by USG in raised bed and PU in conventional planting.

\begin{tabular}{|c|c|c|c|c|c|c|c|c|c|}
\hline \multirow{2}{*}{ Method of fertilizer application } & \multicolumn{9}{|c|}{ Tiller $\left(\right.$ no. $\left.\mathrm{m}^{-2}\right)$ at days after transplanting } \\
\hline & 20 & 30 & 40 & 50 & 60 & 70 & 80 & 90 & 100 \\
\hline USG in bed planting & 91 & 210 & 383 & 370 & 359 & 355 & 346 & 341 & $340 \mathrm{a}$ \\
\hline PU in conventional plot & 88 & 205 & 371 & 363 & 354 & 349 & 342 & 339 & $335 b$ \\
\hline $\mathrm{LSD}$ at $5 \%$ & 2.069 & 4.984 & 9.662 & 5.396 & 4.139 & 14.19 & 2.18 & 9.438 & 2.34 \\
\hline Level of significance & n.s. & n.s. & n.s. & n.s. & n.s. & n.s. & $*$ & n.s. & $* *$ \\
\hline
\end{tabular}

Where n.s., ${ }^{*}$ and $* *$ represent probability of $>0.05, \leq 0.01$ and $\leq 0.001$, respectively. Values were means of three replicates.

\subsection{Leaf Area Index}

Planting method affected the leaf area index (LAI) of transplant aman rice recorded at different days after transplanting (DAT) (Table 4). Plant-to-plant distance in rows also influenced the leaf area index measured at different stages of crop growth. The highest leaf area index was achieved at 60 DAT by USG in bed planting method. After 60 DAT the leaf area index started declining and continued to
100 DAT by USG in bed planting. It was also revealed that at early stage of crop growth the leaf area index by USG in bed planting treatments was lower than conventional planting. The highest LAI was achieved by PU in conventional planting at 80 DAT. After 80 DAT the LAI started to decline and continued to 100 DAT by PU in conventional method. However, LAI differ significantly $(P \leq 0.01)$ between two methods from 20 to 80 DAT (Table 4$)$.

Table 4. Effect of leaf area index by USG in raised bed and PU in conventional planting.

\begin{tabular}{|c|c|c|c|c|c|}
\hline \multirow{2}{*}{ Method of fertilizer application } & \multicolumn{5}{|c|}{ LAI at different DAT } \\
\hline & 20 & 40 & 60 & 80 & 100 \\
\hline Urea super granule (USG) in bed planting & $0.13 b$ & $2.38 \mathrm{~b}$ & $5.22 \mathrm{a}$ & $5.01 \mathrm{a}$ & 3.80 \\
\hline Prilled urea broadcasting in conventional planting & $0.38 \mathrm{a}$ & $2.47 \mathrm{a}$ & $4.92 b$ & $4.97 \mathrm{~b}$ & 3.78 \\
\hline LSD at $5 \%$ & 0.013 & 0.013 & 0.093 & 0.013 & 0.185 \\
\hline Level of significance & $* *$ & $* *$ & $* *$ & * & n.s. \\
\hline
\end{tabular}

Where n.s., ${ }^{*}$ and $* *$ represents probability of $>0.05, \leq 0.01$ and $\leq 0.001$, respectively. Values were means of three replicates.

\subsection{Dry Matter Production}

Planting method affected the dry matter production of transplanted aman rice recoded at different days after transplanting (DAT) (Table 5). In the first date of measurement (20 DAT) it was observed that the PU in conventional method produced higher dry matter yield than USG in bed planting. Likewise, at the final date (100 DAT) highest dry matter production was also recorded by USG in bed planting method than PU in conventional planting. However, dry matter production differs significantly $(P \leq 0.01)$ at 20 to 100 DAT in both planting method except 80 and 90 DAT. 
Table 5. Effect of dry matter production by USG in raised bed and PU in conventional planting.

\begin{tabular}{llllllllll}
\hline \multirow{2}{*}{ Method of fertilizer application } & \multicolumn{7}{c}{ Dry matter production $\left(\mathbf{g ~ m}^{-2}\right)$ at different days after transplanting (DAT) } \\
\cline { 2 - 10 } & $\mathbf{2 0}$ & $\mathbf{3 0}$ & $\mathbf{4 0}$ & $\mathbf{5 0}$ & $\mathbf{6 0}$ & $\mathbf{7 0}$ & $\mathbf{8 0}$ & $\mathbf{9 0}$ & $\mathbf{1 0 0}$ \\
\hline USG in bed planting & $31 \mathrm{~b}$ & $73 \mathrm{~b}$ & $268 \mathrm{a}$ & $433 \mathrm{a}$ & $662 \mathrm{a}$ & $860 \mathrm{a}$ & 1066 & 1196 & $1293 \mathrm{a}$ \\
Prilled urea (PU) broadcasting in conventional planting & $64 \mathrm{a}$ & $127 \mathrm{a}$ & $251 \mathrm{~b}$ & $350 \mathrm{~b}$ & $621 \mathrm{~b}$ & $851 \mathrm{~b}$ & 1062 & 1190 & $1260 \mathrm{~b}$ \\
LSD at 5\% & 2.07 & 2.93 & 2.07 & 19.08 & 21.53 & 2.07 & 13.09 & 5.93 & 10.35 \\
Level of significance & $* *$ & $* *$ & $* *$ & $* *$ & $*$ & $* *$ & n.s. & n.s. & $* *$ \\
\hline
\end{tabular}

Where n.s., ${ }^{*}$ and $* *$ represents probability of $>0.05, \leq 0.01$ and $\leq 0.001$, respectively. Values were means of three replicates.

Crop growth rate

Results from the crop growth rate are shown in Table 6. At the initial stage (20 to 30 DAT) the crop growth rate (CGR) by USG in bed planting is lower than PU in conventional planting. The greatest CGR was observed at 50 to 60 DAT for both USG in bed planting and PU conventional planting method. In contrast, the lowest CGR was observed at 20 to 30 DAT for both by USG in bed planting and PU conventional planting method. However, crop growth rate significantly $(P \leq 0.01)$ differed between both planting methods at all DAT except 70 to 80 and 80 to 90 DAT.

Table 6. Effect of crop growth rate by USG in raised bed and PU in conventional planting.

\begin{tabular}{|c|c|c|c|c|c|c|c|c|}
\hline \multirow{2}{*}{ Method of fertilizer application } & \multicolumn{8}{|c|}{ Crop growth rate $\left(\mathrm{g} \mathrm{m}^{-2}\right.$ day $\left.^{-1}\right)$ at different days after transplanting (DAT) } \\
\hline & 20-30 & $30-40$ & $40-50$ & $50-60$ & $60-70$ & $70-80$ & $80-90$ & $90-100$ \\
\hline Urea super granule in bed planting & $4.20 \mathrm{~b}$ & $19.5 \mathrm{a}$ & $16.5 \mathrm{a}$ & $22.9 b$ & $19.8 b$ & 20.6 & 13.0 & $9.30 \mathrm{a}$ \\
\hline LSD at $5 \%$ & 0.33 & 0.59 & 0.47 & 0.13 & 1.86 & 0.56 & 0.49 & 0.96 \\
\hline Level of significance & $* *$ & $* *$ & $* *$ & ** & * & n.s. & n.s. & $*$ \\
\hline
\end{tabular}

Where n.s., ${ }^{*}$ and $* *$ represents probability of $>0.05, \leq 0.01$ and $\leq 0.001$, respectively. Values were means of three replicates.

\subsection{Weed Population}

Weed population and dry biomass were greatly influenced by different planting methods of transplanted aman rice (Table 7). The USG in bed planting method reduced weed population resulting in lower dry biomass than PU in conventional planting. The PU in conventional method had significantly $(P \leq 0.01)$ higher weed vegetation than raised bed planting.

Table 7. Effect of weed growth by USG in raised bed and PU in conventional planting.

\begin{tabular}{|c|c|c|}
\hline \multirow{2}{*}{ Method of fertilizer application } & \multicolumn{2}{|l|}{ Weed vegetation } \\
\hline & Weed vegetation population $\left(\mathrm{no}^{-} \mathrm{m}^{-2}\right)$ & Dry biomass $\left(\mathrm{kg}^{\left.-\mathrm{ha}^{-1}\right)}\right.$ \\
\hline Urea super granule in bed planting & $110 \mathrm{~b}$ & $103.31 \mathrm{a}$ \\
\hline Prilled urea broadcasting in conventional planting & $380 \mathrm{a}$ & $337 b$ \\
\hline LSD at $5 \%$ & 4.984 & 1.873 \\
\hline Level of significance & $* *$ & $* *$ \\
\hline
\end{tabular}

Where $* *$ represent probability of $\leq 0.001$. Values were means of three replicates.

\subsection{Irrigation Water}

Amount of water required for different irrigations differed remarkably between the conventional and bed planting methods (Table 8). The PU in conventional planting received a higher amount of water at every irrigation and the total amount was $142.66 \mathrm{~cm}$. The total amount of irrigation water received by USG in bed planting was $103.44 \mathrm{~cm}$. Result showed that total water savings by USG in bed over PU in conventional method was $40 \%$.

Table 8. Irrigation water savings by USG in raised bed and PU in conventional planting method.

\begin{tabular}{lllllll}
\hline \multirow{2}{*}{$\begin{array}{l}\text { Method of fertilizer } \\
\text { application }\end{array}$} & \multicolumn{2}{l}{ Water required at different times of irrigation $\mathbf{( c m}$ ) } & \multicolumn{2}{l}{$\begin{array}{l}\text { Water saved over } \\
\text { conventional method (\%) }\end{array}$} \\
\cline { 2 - 6 } & Land preparation & Transplanting & Reproductive stage & Rainfall & Total & 40 \\
\hline USG in bed planting & - & $5.62 \mathrm{~b}$ & $45.32 \mathrm{~b}$ & 52.50 & $103.44 \mathrm{~b}$ & 40 \\
PU broadcasting in & 13.06 & $6.20 \mathrm{a}$ & $70.90 \mathrm{a}$ & 52.50 & $142.66 \mathrm{a}$ \\
conventional planting & & 0.262 & 0.296 & 0.654 & 2.094 \\
LSD at 5\% & 0.059 & $*$ & $* *$ & n.s. & $* *$ \\
Level of significance & - & - & &
\end{tabular}

Where n.s., * and ** represents probability of $>0.05, \leq 0.01$ and $\leq 0.001$, respectively. Values were means of three replicates. "-"indicates data not available. 


\subsection{Water Use Efficiency}

Water use efficiency for grain and biomass production by USG in bed planting was $35.40 \mathrm{~kg} \mathrm{ha}^{-1} \mathrm{~cm}^{-1}$ and $98.99 \mathrm{~kg} \mathrm{ha}^{-1} \mathrm{~cm}^{-1}$, respectively (Table 9). In contrast, water use efficiency for grain production and biomass production in conventional planting was $30.63 \mathrm{~kg} \mathrm{ha}^{-1} \mathrm{~cm}^{-1}$ and $65.11 \mathrm{~kg} \mathrm{ha}^{-1} \mathrm{~cm}^{-1}$, respectively. However, water use efficiency for grain production and biomass production by USG bed planting over PU in conventional was $49 \%$ and $40.88 \%$, respectively.

Table 9. Water use efficiency by USG in raised bed and PU in conventional planting method.

\begin{tabular}{lll}
\hline Method of fertilizer & Water use efficiency savings by foliar spray in bed planting of rice over conventional method \\
\cline { 2 - 3 } application & Water use efficiency for grain production $\left(\mathbf{k g ~ h a}^{-1} \mathbf{c m}^{-1}\right)$ & Water use efficiency for biomass production $\left(\mathbf{k g ~ h a}^{-1} \mathbf{c m} \mathbf{c m}^{-1}\right)$ \\
\hline USG in bed planting & $35.40 \mathrm{a}$ & $98.99 \mathrm{a}$ \\
PU in conventional planting & $30.63 \mathrm{~b}$ & $65.11 \mathrm{~b}$ \\
LSD at 5\% & 1.083 & 2.121 \\
Level of significance & $* *$ & $* *$ \\
\hline
\end{tabular}

Where $* *$ represent probability of $\leq 0.001$. Values were means of three replicates.

\subsection{Agronomic Efficiency of $N$ Fertilizer}

Agronomic efficiency of $\mathrm{N}$ fertilizer by the USG in raised bed was $55.04 \%$ (Table 10). On the other hand, agronomic efficiency for PU in conventional planting was $43.67 \%$. Agronomic efficiency of $\mathrm{N}$ fertilizer by USG in raised bed was significantly $(P \leq 0.01)$ higher than the $\mathrm{PU}$ in conventional planting method.

Table 10. Agronomic efficiency of fertilizer by USG in raised bed and PU in conventional planting method.

\begin{tabular}{ll}
\hline $\begin{array}{l}\text { Method of Fertilizer } \\
\text { application }\end{array}$ & Agronomic efficiency of fertilizer (\%) \\
\hline USG in bed planting & $55.04 \mathrm{a}$ \\
PU in conventional method & $43.67 \mathrm{~b}$ \\
LSD at 5\% & 4.225 \\
Level of significance & $* *$ \\
\hline
\end{tabular}

Where $* *$ represent probability of $\leq 0.001$. Values were means of three replicates.

\section{Discussions}

\subsection{The USG Techniques in Bed Planting Increases Plant Growth Parameters than the PU in Conventional Flat Methods}

The increase in plant height by the USG in raised bed over the PU in conventional method was $4.46 \%$ (Table 2). Other studies also found that the USG techniques in bed planting produced taller plants than the PU in conventional cultivation techniques (Singh and Singh, 1986; Reddy and Mitra, 1985; Roy, 1988). This could be due to effective utilization of nitrogen fertilizer by rice plant during their vegetative growing period. Likewise, Puckridge et al, (1991) found that the paddy rice plant $\mathrm{N}$ uptake increased immediate after super granule placement into the soil during their vegetative growth period. They suggested that this increase in $\mathrm{N}$ uptake by rice plant during their vegetative growth period could be due to variation of stress on rice plants.

The USG treated plot in bed planting significantly recorded higher number of tiller and panicles $\mathrm{m}^{-2}$ compared to the PU in conventional planting method (Table 2). Similarly, Joseph et al, (1991) found that tiller number $\mathrm{m}^{-2}$ was 265 and 309 for PU and USG, respectively. Similarly, Thakur (1991) found that panicles $\mathrm{m}^{-2}$ was 170 and 289 for PU and USG, respectively. However, they conducted their experiment in conventional flat method. This indicates that the USG is always superior to the PU in any condition for rice production. This could be due to the fact that the increase in $\mathrm{N}$ levels was responsible for increased number of leaves, resulting in higher photosynthesis, metabolic activity and cell division, which consequently increased growth and hence yield attributes (Jaiswal and Singh, 2001). Likewise, Jaisal and Singh (2001) also suggested that deep placement of the USG played a vital role for adequate nutrient supply with minimizing losses of nitrogen, $\mathrm{NH}_{3}$ volatilization, nitrification and denitrification which ultimately increased the plant growth characteristics in raised bed plot.

\subsection{Grain and Straw Yields Attributed to Higher in Raised Bed for USG than Conventional PU Technique}

Higher grain and straw yields for the USG treated plots in bed planting were attributed to higher number of tiller and panicle (Tables 2 and 3). The superiority of the USG in bed planting over the PU in conventional planting regarding grain and straw yields of rice was found in many other investigations (De Datta, 1987; Bhuiyan et al, 1985; Choudhury and Bhuiyan, 1994). Similarly, Jena et al, (2003) found that deep placement of the USG significantly improved grain yield, straw yield and nitrogen use efficiency of rice and reduced the volatilization loss of ammonia relative to the application of the PU. Regardless of that, Lal et al, (1988) found that transplanted rice grain yield was 3.5 and $4.8 \mathrm{t} \mathrm{ha}^{-1}$ for PU and USG, respectively. This finding indicated that the USG is also suitable in conventional plot other than raised bed. They speculated that a high yield with the USG application seems to be associated with high $\mathrm{N}$ uptake due to higher $\mathrm{N}$ availability. Other study suggested that high yield of rice for placement of the USG in reduced soil layer could be due to decrease in $\mathrm{N}$ loss by volatilization, denitrification and aquatic weed competition including algal immobilization (Thomas and Prasad, 1982).

Our speculation is that existing conventional practice by farmers in Bangladesh often use urea inefficiently either 
because of this optimum is unknown, or the recommended doses is misleading or because of limited access to fertilizer. Likewise, Tran et al, (1989) reported that fertilizer and water use inefficiencies have substantially contributed to low yield in rice. Similarly, Pillai and Vamadevan (1978) speculated that the apparent reason for increased grain yield may be due to slower rate of urea hydrolysis of large sized urea super granule. Further, as the material was placed in the reduce zone of soil, losses of nitrogen due to nitrification-denitrification and leaching were minimized. Thus, the efficiency of applied nitrogen was increased which in turn contributed to increased grain yield (Pillai and Vamadevan 1978).

\subsection{Nitrogen Use Efficiency Was Greater in the USG in Raised Bed than the PU in Conventional Method}

The USG in raised bed had significantly $(P \leq 0.01)$ lower nitrogen fertilizer utilization efficiency than the conventional plot (Table 10). Wes Emmott et al, (2013) reported that at basal dose $\mathrm{N}$ required $50 \mathrm{~kg} \mathrm{ha}^{-1}$. At active tillering stage $\mathrm{N}$ required by the rice plant was $89 \mathrm{~kg} \mathrm{ha}^{-1}$. The $\mathrm{N}$ required at the panicle initiation stage by the rice plant was $104 \mathrm{~kg} \mathrm{ha}^{-1}$ at heading stage $\mathrm{N}$ required by rice plant was $30 \mathrm{~kg} \mathrm{ha}^{-1}$. The highest $\mathrm{N}$ required by the rice plant was observed at panicle initiation stage. However, the USG was applied 7 days after transplanting at rate of $81 \mathrm{~kg}$ $\mathrm{ha}^{-1}$ in our experiment. So $\mathrm{N}$ required by the rice plant was $37 \mathrm{~kg} \mathrm{ha}^{-1}$. In the method of deep placement $(7-10 \mathrm{~cm})$ of USG in bed planting the fertilizer was applied at active tillering stage. Because of large size of USG allow slower hydrolysis rate of urea fulfilled the highest demand of $\mathrm{N}$ at the panicle initiation stage. This may save the amount of $\mathrm{N}$ fertilizer required by the rice plant. Joseph et al, (1991) also found that nitrogen use efficiency was higher in USG than the conventional PU technique. Likewise, BRRI (2008) reported that nitrogen fertilizer use efficiency can be increased up to $20-25 \%$ and $30 \%$ of urea fertilizer can be saved by the USG application than the PU conventional cultivation method. Similarly, Thakur (1991) found that nitrogen use efficiency for PU and USG were 26.1 and 32.8 $\mathrm{kg}$ grain $\mathrm{kg}^{-1} \mathrm{~N}^{-1}$, respectively. This might be due to the placement of USG in the reduced zone and its bigger size may have increased its efficiency by minimizing loss of $\mathrm{N}$ through ammonia volatilization and denitrification (Nommick, 1976). There also may be possibility that the USG were placed below soil surface that minimize $\mathrm{N}$ loss through runoff and volatilization. Similarly, Cao et al, (1984) speculated that with deep placement of urea, the losses due to $\mathrm{N}_{2}$ denitrification and $\mathrm{NH}_{3}$ volatilization can be reduced, which accounts for the superiority of deep placement of USG to PU application. Likewise, Thakur (1991) opined that the size of USG and less losses or better utilization through deep placement of the USG is responsible for higher nitrogen use efficiency than the PU in conventional flat method. Regardless of that, the apparent reason for increased nitrogen use efficiency for the USG may be due to slower rate of urea hydrolysis from the large size USG and this release is in synchrony with the rice plant requirements. Further, as the USG was placed in the reduced zone of soil, losses of nitrogen due to nitrification-denitrification and leaching were minimized. Thus, the efficiency of applied nitrogen was increased which in turn contributed to increased grain yield (Pillai and Vamadevan, 1978).

\subsection{The USG in Raised Bed Attributed Better Agronomic Efficiency of $N$ Fertilizer and Suppress the Activities of Weed Growth than the PU in Conventional Method}

Agronomic efficiency of $\mathrm{N}$ fertilizer was $12 \%$ higher using USG in bed planting over PU in conventional planting (Table 10). Higher agronomic efficiency of $\mathrm{N}$ fertilizer with USG over PU was also found in some other investigations (Choudhury and Bhuiyan, 1994; Choudhury et al, 1994). Our speculation is that the higher agronomic efficiency of $\mathrm{N}$ fertilizer using USG over PU could be due to the high recovery of applied $\mathrm{N}$ in the field. This might possibly be due to different losses like denitrification, ammonia volatilization, runoff and immobilization were too low in the USG than the PU. Further, hence the placement of USG on raised bed can provide agronomic benefits and minimize $\mathrm{N}$ application rate and loss.

Weed population were significantly $(P \geq 0.01)$ higher in the conventional PU application than the USG in raised bed planting method (Table 7). This may be better agronomic management practices and deep placement of USG in raised bed than conventional PU application. However, Mohanty et al, (1999) speculated that the USG application in rice field retarded weed growth due to limited nitrificationdenitrification process and biological nitrogen fixation is promoted under reduced floodwater $\mathrm{N}$ concentration.

\subsection{The USG in Raised Bed Use Less Water and Has Higher Water Use Efficiency than the Conventional Flat Method}

The USG in bed planting saved $40 \%$ irrigation water than the conventional flat method. This water saving mainly occurred in transplanting and reproductive stage (Table 8). Likewise, water use efficiency was significant by higher $(P \leq 0.001)$ in raised bed for USG than the conventional flat method (Table 9). Other study like Kahlown (2006) found that raised bed system generally use 10 to $30 \%$ less water than the amount applied to farmers to their flooded basins. Thompson et al, (2003) also showed that irrigation water savings of about 14\% using bed compared with flat method. Likewise, Beecher et al, (2006) found that raised bed (17.2 $\left.\mathrm{ML} \mathrm{ha}^{-1}\right)$ use significantly less water than the conventional flat (18.7 ML ha-1) method. They speculated that saving in irrigation water use is related to the amount of time a crop is intermittently irrigated, thus the longer ponding occurs, the lesser it will be the water will be saving. These findings concluded that continuous submergence is not a must for rice production. Saturated soil condition is optimum for rice production. 


\section{Conclusions}

The findings of this study demonstrated that the USG in bed planting is superior to PU broadcasting in conventional planting method for rice production. Placement of USG in raised bed produced higher number of panicles per unit area, panicle weight, number of grains per panicle and 1000-grain weight, which ultimately gave the highest grain yield than the PU in conventional plot. This study also concluded that the USG application within raised bed proved beneficial over conventional PU technique, especially with respect to grain yield, yield attributes, agronomic efficiency and water use efficiency. Deep placement of the USG in raised bed effectively increased $\mathrm{N}$-use efficiency as compared to conventionally applied prilled urea. The placement of the USG below plough layer $(5 \mathrm{~cm})$ is considered the best method to decrease $\mathrm{N}$ losses and thereby to increase fertilizer use efficiency. This study also suggests that the deep placement of the USG in raised bed is feasible for water and nitrogen use efficiency and reduction in soil compaction.

It was found from our previous studies that raised bed system for rice production achieve higher yield than conventional flat method (Bhuyan et al, 2012a; Bhuyan et al, 2012b). The deep placement of urea super granule for raised bed planting, new rice based farming systems, offers many potential advantages. Therefore, deep placement of the USG at $7-10 \mathrm{~cm}$ depth (reduced soil layer) on raised bed is one of the most efficient $\mathrm{N}$ management techniques developed for rice production. There is a good prospect of utilization of this technology to benefit the rice farmers. Further experiment will be conducted to distinguish role of urea super granule application on raised bed as compared to conventional method for transplanted boro/winter rice (completely depends on irrigation) production.

\section{Acknowledgements}

The authors are thankful to the farmer who leases his land for this experiment. The author also thanks to the pump operator for his kind help to irrigate the land. The authors are deeply indebted to the authorities of Bangladesh Rice research institute (BRRI), Local weather office, Chuadanga and seed processing unit, Bangladesh Agricultural Development Corporation (BADC), Chuadnaga for their assistance and constructive suggestion.

\section{References}

[1] Bangladesh Rice Research Institute (BRRI). 2008. “Adhunik Dhaner Chash"- Bengali Version, Bangladesh Rice Research Institute, Gazipur-1701.

[2] Bangladesh Rice Research Institute (BRRI). 2007. Impact of LCC and USG on rice production in same selected areas. Annual Research Review Report, Agricultural Economics Division, Bangladesh Rice Research Institute, Gazipur, 14-17 January.

[3] BARC.2005. Bangladesh Agricultural Research Council,
Fertilizer Recommendation Guide, Ministry of Agriculture, Governments of the People's Republic of Bangladesh, Dhaka, Bangladesh, p. 174-175.

[4] Beecher, H. G., Dunn, B. W., Thompson, J. A., Humphreys, E., Mathews, S. K., and Timsina, J. 2006. Effect of raised beds, irrigation and nitrogen management on growth, water use and yield of rice in south-eastern Australia. Australian Journal of Experimental Agriculture 46: 1363-1372.

[5] Bhuiyan, N. I., Mazid, M. A., Saleque, M. A.1985. Fertilizer nitrogen deep placement status of research by BRRI. IN Proceedings Fertilizer Nitrogen Deep Placement for Rice. Dhaka, Bangladesh: Bangladesh Agricultural Research Council. PP. 27-36.

[6] Bhuyan, M. H. M., Ferdousi, M. R., Iqbal, M. T. 2012a. Yield and growth response to transplanted aman rice under raised bed over conventional cultivation method. ISRN Agronomy (doi:10.5402/2012/646859).

[7] Bhuyan, M. H. M., Ferdousi, M. R., Iqbal, M. T. 2012b. Foliar spray of nitrogen fertilizer on raised bed increases yield of transplanted aman rice over conventional method. ISRN Agronomy (doi:10.5402/2012/184953).

[8] BRRI. 2008. Adhunik Dhaner Chash, 14th Edition, Bangladesh Rice Research Institute, Gazipur-1701, Bangladesh, pp.13-15.

[9] BRRI. 2009. Bangladesh Rice Research Institute, Fact sheet; soil \& fertilizer management. pp. 3-5.

[10] Cao, Z. H., De Datta, S. K., Fillery, I. R P. 1984. Effect of placement methods on floodwater properties and recovery of applied N ( ${ }^{15} \mathrm{~N}$ - labeled urea) in wetland rice. Soil Science Society of America Journal 48(1): 196-203.

[11] Choudhury, A. T. M. A., Bhuiyan, N. I. 1994. Effect of rates and methods of nitrogen application on grain yield and nitrogen uptake of wetland rice. Pakistan Journal of Scientific and Industrial Research 37 (3): 104-107.

[12] Choudhury, A. T. M. A., Byuiyan, N. I., Hashem, M. A., Matin, M. A.1994. Nitrogen fertilizer management in wetland rice culture. Thai Journal of Agricultural Science 27(3): 259-267.

[13] Choudhury, A. T. M. A., Khanif, Y. M. 2011. Evaluation of effects of nitrogen and magnesium fertilization on rice yield and fertilizer nitrogen efficiency using ${ }^{15} \mathrm{~N}$ tracer technique. Journal of Plant Nutrition 24(6): 855-871.

[14] De Datta, S. K.1978. Fertilizer management for efficient use in wetland rice soils. In Soils and Rice. Los Banos, Phlippines: International Rice Research Institute. p. 671-679.

[15] De Datta, S. K.1981. Principles and Practices of Rice Production. New York, USA: John Wiley Sons, Inc.

[16] De Datta, S. K.1987. Advances in Soil Fertility Research and Nitrogen Fertilizer Management for Lowland Rice. In Efficiency of Nitrogen Fertilizers for Rice. Los Banos, Philippines: International Rice Research Institute. P. 27-41.

[17] Goswami, N. N., Banerjee, N. K. 1978. Phosphorus, potassium and other microelements. in Soils and Rice. Los Banos, Philippines: International Rice Research Institute. PP. 561-580.

[18] Hobbs, P. R.2001. Tillage and Crop Establishment in South Asian Rice-Wheat Systems, Journal of Crop Production 4(1): 122. 
[19] Jaisal, V. P., Singh, G. R.2001. Performance of urea super granule and prilled urea under different planting methods in irrigated rice (Oryza sativa). Indian Journal of Agricultural Sciences 71(3): 187-189.

[20] Jat, M. L., Singh S, Rai., H K R S, Chhokar., Sharma S. K., Gupta, R K.2005. Furrow Irrigated Raised Bed (FIRB) Planting Technique for Diversification of Rice-Wheat System in Indo-Gangetic Plains. Japan Association for International Collaboration of Agriculture and Forestry 28 (1): 25-42.

[21] Jena, D., Misra, C., Bandyopadhyay, K K.2003. Effect of prilled urea and urea super granules on dynamics of ammonia volatilisation and nitrogen use efficiency of rice. Journal of the Indian Society of Soil Science 51(3): 257- 261.

[22] Joseph, K., Tomy, P. J., Nair, N. R. 1991. Effect of sources and levels of nitrogen on the growth, yield and nitrogen use efficiency of wetland rice. Indian Journal of Agronomy 36(1): 40-43.

[23] Lal, P., Gautam, R. C., Bishat, P. S., Pandey, P. C.1988. Agronomic and economic evaluation of urea super granule and sulphur coated urea in transplanted rice. Indian Journal of Agronomy 33(2): 186-190.

[24] Kahlown, M A. 2006. Low cost, innovative water conservation practices in irrigated agriculture. The $2^{\text {nd }}$ International Conference on Water Resources and Arid Environment. pp. 9-10.

[25] Kuma, r D., Devakumar, C., Kumar, R., Das, A., Panneerselvam, P., Shivay, Y. S. 2010. Effect of neem-oil coated prilled urea with varying thickness of neem-oil coating and nitrogen rates on productivity and nitrogen-use efficiency of lowland irrigated rice under indo-gangetic plains. Journal of Plant Nutrition 33: 1939-1959.

[26] Mohanty, S. K., Singh, U., Balasubramanian, V., Jha, K P. 1999. Nitrogen deep-placement technologies for productivity, profitability, and environmental quality of rainfed lowland rice systems. Nutrient Cycling in Agroecosystems 53: 43-57.

[27] Nommik, H.1976. Further observations on ammonia loss from urea applied to forest soil with special reference to the effect of pellet size. Plant and Soil 45: 279-282.

[28] Pillai, K. G. Vamadevan, VK.1978. Studies on the integrated nutrient supply system for rice. Fertilizer News 23(3): 11-14.

[29] Ponnamperuma, F. N.1972. The Chemistry of submerged Soils. Advances in Agronomy 24: 29-96.

[30] Puckridge, D. W. Wiengweera., A Thongbai, P Sangtong, P Sattarasart, A Kongchum, M Runtan S.1991. Nitrogen uptake by deepwater rice during the preflood and flooded phases, in relation to dry matter and grain production. Field Crop Research 27: 315-336.

[31] Ram, J., Y, Singh., D. S Kler., K. Kumar., I, Humphreys., J. Timsina.2005. Performance crops and alternative cropping systems on permanent raised beds in the Indo-Gangetic plains of north-western India. Presented in ACIAR Wordshop on Permanent Bed Planting Systems. 1-3 Mar. 2005. Griffith, NSW, Australia.

[32] Reddy, MD Mitra, B N.1985. Response of rice to different forms of urea and phosphorus fertilization under intermediate deepwater conditions. Plant and soils 84(3): 431-435.

[33] Roy, B.1988. Coated and modified urea materials for increasing nitrogen use efficiency of lowland rice in heavy clay soils. Fertilizer Research 15(2): 101-109.

[34] Sahrawat, K L. 2000. Marco and micronutrients removed by upland and lowland rice cultivars in West Africa. Communications in Soils Science and Plant Analysis 31(5 \& 6): 717-723.

[35] Singh, B. K., Singh, R P.1986. Effect of modified urea materials on rain fed low land transplanted rice and their residual effect on succeeding wheat crop. Indian Journal of Agronomy 31(2): 198-200.

[36] Singh, S., Ladhab JK Gupta., RK, Bhushana L., Raob, A. N. 2008. Weed management in aerobic rice systems under varying establishment methods. Crop Protection 27: 660-671.

[37] Thakur, R. B.1991. Relative efficiency of prilled urea and modified urea fertilizers on rainfed lowland rice. Indian Journal of Agronomy 36(1): 87-90.

[38] Thomas, J., Prasad R.1982. On the nature of mechanism responsible for the higher efficiency of the urea super granules for rice. Plant and Soil 69: 127-130.

[39] Thompson J., Griffin D., North, S.2003. Improving the water use efficiency of rice. Co-operative research centre for sustainable rice production, Final report No. 1204, Yanco, NSW.

[40] Tran, D. V., Marathée, J. P.1994. Major Issues in Asian RiceWheat Production Systems. Sustainability of Rice-Wheat Production Systems in Asia. RAPA Publication: 1994/11, 6167.

[41] Wetsellar, R.1985. Deep point-placed urea in a flooded soil: a mechanistic view. Special Publications, International fertilizer Development Centre (IFDC), U. S. A. SP-6. pp. 7-14.

[42] Wes Emmott., Tyler Kernighan, Christine Tobin, Hugo Gonzalez, Blair Freeman.2013. Growth stages of rice-plant Agriculture. Source: www.plant.uoguelph.ca /courses/pbio3110/documents/Rice_08.pdf

[43] Zia, M S Aslam., M Gill., M A.1992. Nitrogen management and fertilizer use efficiency for lowland rice in Pakistan. Soil Science and Plant Nutrition 38(2): 323-330. 